\title{
Efek Ekstrak Etanolik Daun Sirsak pada Proliferasi dan Apoptosis Sel HeLa yang Dimediasi oleh p53
}

\section{The Effect of Annona Muricata Leaf on Proliferation and Appoptosis of HeLa Cells Mediated by $p 53$}

\author{
Ermin Rachmawati ${ }^{1}$, Setyawati Karyono ${ }^{2}$, Hidayat Suyuti ${ }^{3}$ \\ ${ }^{1}$ Departemen Fisiologi Fakultas Kedokteran Universitas Lampung Bandar Lampung \\ ${ }^{2}$ Laboratorium Farmakologi Fakultas Kedokteran Universitas Brawijaya Malang \\ ${ }^{3}$ Laboratorium Biokimia-Biomolekuler Fakultas Kedokteran Universitas Brawijaya Malang
}

\begin{abstract}
ABSTRAK
Kanker serviks merupakan penyebab utama kedua kematian kanker pada wanita di seluruh dunia, menyebabkan 240.000 kematian setiap tahunnya. Ekstrak daun Annona muricata berpotensi baik sebagai obat anti kanker. Tujuan dari penelitian ini adalah untuk mengetahui pengaruh ekstrak etanol daun sirsak (Annona muricata) dalam menghambat dan menginduksi aktivasi apoptosis yang dimediasi oleh stabilisasi p53 pada pertumbuhan kanker serviks. Sebuah percobaan in vitro dilakukan dengan menggunakan kultur sel HeLa. Penghambatan proliferasi diukur dengan MTT assay. Apoptosis dideteksi dengan menggunakan flowcytometry Annexin V Biotin Kit Apoptosis Detection. Konfirmasi dan perhitungan ekspresi p53 ditentukan oleh imunocytochemistry. Ekstrak etanol dari daun Annona muricata secara efektif menghambat proliferasi sel HeLa dengan dosis tertentu pada paparan 48 jam. Nilai IC50 ekstrak etanol daun Annona muricata adalah $111,75 \mathrm{ug} / \mathrm{ml} .200 \mathrm{mg} / \mathrm{ml}$ ekstrak menginduksi apoptosis sel HeLa tergantung dari lama pemaparan. Ekstrak ini juga meningkatkan ekspresi p53 sel HeLa tergantung dosis pemberian (25, 50, 100, $200 \mu \mathrm{g} / \mathrm{ml}$ ) dan lama pemberian ( $24 \mathrm{dan} 48$ jam). Dapat disimpulkan bahwa ekstrak etanol daun sirsak menghambat pertumbuhan sel HeLa dan menginduksi apoptosis. Mekanisme ekstrak daun sirsak menghambat proliferasi dan apoptosis inducing berhubungan dengan stabilisasi dan aktivasi p53.
\end{abstract}

Kata Kunci: Daun Annona muricata, apoptosis, ekstrak etanol, proliferasi, ekspresi p53

\begin{abstract}
Cervical cancer is the second leading cause of cancer mortality in women worldwide, causing 240.000 deaths annually. Annona muricata leaves extract have emerged as potentially promising anticancer drugs. The purpose of this study was to investigate the effect of ethanolic extract of soursoup (Annona muricata) leaves on inhibiting cervical cancer growth and induce apoptosis which is mediated by 553 stabilization and activation. An invitro experiment was performed using HeLa cell culture. The proliferation inhibition was measured by MTT assay. Apoptosis was detected by flowcytometry using Annexin $V$ Biotin Apoptosis Detection Kit. Confirmation and calculation of p53 expression was determined by imunocytochemistry. Ethanolic extract of Annona muricata leaves were effectively inhibit HeLa cells proliferation dose dependent manner by 48 hours exposure. The $I C_{50}$ values of ethanolic extract of Annona muricata leaves was $111.75 \mu \mathrm{g} / \mathrm{m} I$. The $200 \mu \mathrm{g} / \mathrm{ml}$ extract induced apoptosis in HeLa cells time dependent manner. The extract also increased the expression of p53 in Hela cells dose $(25,50,100,200 \mu \mathrm{g} / \mathrm{ml})$ and time (24 and 48 hour) dependent manner. It can be concluded that ethanolic extract of soursoup leaves inhibit HeLa cell growth and induced apoptosis in HeLa cells. The mechanism of extract-inhibiting proliferation and inducing apoptosis might be associated with the stabilization and activation of $p 53$.
\end{abstract}

Keywords: Annona muricata leaves, apoptosis, ethanolic extract, proliferation, p53 expression

Jurnal Kedokteran Brawijaya, Vol. 27 No. 1, Februari 2012; Korespondensi: Ermin Rachmawati. Departemen Fisiologi Fakultas Kedokteran Universitas Lampung Bandar Lampung, Jl. Prof. Soemantri Brojonegoro No.1 Gedong Meneng Bandar Lampung 35145 Tel. (0721) 701609Email:ermin00@yahoo.com 


\section{PENDAHULUAN}

Kanker serviks adalah penyebab mortalitas kedua akibat kanker pada wanita di seluruh dunia yang menyebabkan 240.000 kematian setiap tahunnya. Sekitar 490.000 kasus baru dilaporkan tiap tahun. Lebih dari $80 \%$ kanker serviks terjadi di negara berkembang (1).

Etiologi utama kanker serviks adalah infeksi persisten virus Human Papilloma Virus (HPV). Infeksi dengan HPV mengakibatkan terjadinya integrasi genom DNA HPV dengan host sehingga terjadi gangguan atau hilangnya gen E2 virus yang menyebabkan terekspresinya onkogen virus E6 dan E7. Produk E6 dan E7 menghambat aktivitas tumor supresor p53 dan protein $\mathrm{Rb}(2,3)$. P53 adalah protein tumor supresor yang berperan penting pada siklus sel. P53 berfungsi sebagai faktor transkripsi gen-gen yang terlibat pada fase checkpoint siklus sel dan proses apoptosis. Pada sebagian besar kanker, p53 mengalami mutasi. Pada kanker serviks, modifikasi p53 sebagian besar adalah modifikasi posttranslasional, dimana protein onkogenik E6 bekerjasama dengan E6AP sebagai E3 ubikuitin ligase memediasi degradasi proteosomal dari p53 (4). Proliferasi sel yang tidak terkontrol serta penurunan apoptosis merupakan salah satu fungsi seluler yang berubah pada kanker serviks yang diakibatkan degradasi p53 $(5,6)$.

Modalitas terapi yang telah ditentukan untuk pengobatan kanker serviks saat ini tidak seluruhnya dapat menyembuhkan kanker serviks. Terjadinya kekambuhan pasca radioterapi masih sering dijumpai pada pasien kanker serviks (7). Radioterapi dan kemoterapi juga memiliki beberapa keterbatasan. Kemampuan sinar yang biasa digunakan untuk radioterapi mengalami penurunan efektivitas seiring dengan peningkatan ukuran tumor, karena penambahan dosis yang diberikan melebihi batas toksisitasnya pada jaringan dan organ normal manusia. Penggunaan obat kimia seperti kemoterapi tidak hanya membunuh sel tumor namun juga merusak sel darah yang menyebabkan penurunan fungsi imun atau bahkan kematian yang disebabkan dari komplikasi akibat efek samping obat yang serius (8). Data-data publikasi satu dekade belakangan ini menyebutkan bahwa sel kanker serviks mulai resisten terhadap pengobatan dengan metode radiasi dan kemoterapi $(7,9)$.

Berdasar fakta-fakta tersebut, saat ini pengembangan obat anti neoplastik baru menjadi isu kunci dan pilihan strategis untuk menggantikan pengobatan kanker lama atau sebagai usaha meningkatkan sensitivitas modalitas terapi yang telah ada sebelumnya. Salah satu alternatif pengobatan anti kanker yang sedang dikembangkan adalah obat herbal. Studi farmakologis menunjukkan bahwa ekstrak herbal terdiri dari nutrisi penting, beberapa dengan bahan-bahan yang memiliki aktivitas anti tumor, antioksidan dan anti mutasi dengan berbagai target yang saling bekerja secara sinergis (8).

Annona muricata Linn yang juga biasa dikenal dengan nama sirsak tersebar luas di daerah tropis dan nontropis (10). Acetogenin merupakan satu bahan aktif yang telah berhasil diisolasi dari daun sirsak dan terbukti dapat membunuh sel kanker seperti kanker hepatoma, cell line kanker ovarium, payudara, kandung kemih dan kulit pada dosis yang sangat rendah $(11,12)$. Acetogenin juga telah dibuktikan dapat membunuh sel kanker yang mengalami resistensi (MDR) (13). Beberapa mekanisme acetogenin dalam melawan sel kanker telah banyak diteliti, diantaranya adalah inhibisi kompleks I transport elektron mitokondria yang akan menyebabkan deplesi ATP, sehingga sel kanker mati $(14,15)$. Mekanisme lainnya adalah bahwa acetogenin khususnya jenis annonacin mampu memberhentikan siklus sel kanker pada fase G1 dan menghambat kemajuan siklus sel menuju fase $\mathrm{S}$ dengan cara menginduksi ekspresi p53, p21, Bax dan Bad pada cell line kanker prostat (12).

Hasil penelusuran literatur sampai saat ini belum berhasil menemukan adanya pembuktian ilmiah bahwa ekstrak daun sirsak dapat menurunkan proliferasi, meningkatkan apoptosis pada sel HeLa yang merupakan model cell line kanker serviks. Uji eksperimen ini bertujuan menjelaskan mekanisme molekuler ekstrak etanolik daun sirsak dalam menurunkan proliferasi dan meningkatkan apoptosis sel HeLa yang diduga diperantarai oleh peningkatan stabilisasi dan aktivasi $p 53$.

\section{METODE}

\section{Penumbuhan Sampel Penelitian}

Sel HeLa (CCRC-UGM) dikultur sebagai monolayer aderen dalam medium RPMI 1640, FBS $20 \%$ v/v dan $1 \%$ penisilinstreptomisin. Sel diinkubasi dalam inkubator suhu $37^{\circ} \mathrm{C} 5 \%$ $\mathrm{CO}_{2}$. Subkultur dilakukan apabila sel konfluen $90 \%$. Medium lama dalam flask kultur dibuang dan sel dibasuh dengan masing-masing D-PBS, EDTA dan tripsin 0,025\%, diinkubasi selama 2 menit dalam inkubator pada suhu $37^{\circ} \mathrm{C} 5 \% \mathrm{CO}_{2}$. Kemudian ditambahkan FBS $20 \%$ dan semua aspirat disentrifugasi pada kecepatan 900 rpm 5 menit. Setelah supernatan dibuang, dilakukan penambahan media pertumbuhan baru, kemudian dibagikan ke dalam beberapa flask kultur.

\section{Ekstraksi Daun Sirsak}

Bahan utama yang digunakan adalah daun sirsak (Annona muricata L) yang diperoleh dari daerah Malang. Daun sirsak yang digunakan diambil dari pohon yang telah berbuah, dengan pilihan pertama daun ke-4 dan ke-5 dari ujung diambil sebanyak 10 lembar, kemudian dilakukan penimbangan. Daun dibersihkan dengan air mengalir, dikeringkan pada suhu $40-60^{\circ} \mathrm{C}$ (16). Sampel kering diserbuk dan ditimbang masing-masing 100 gram. Serbuk sampel kering direndam dengan etanol sampai dengan volume $900 \mathrm{ml}$. Dilakukan pengocokan dan didiamkan semalam sampai mengendap (proses maserasi). Supernatan disaring untuk mendapatkan filtrat. Pemisahan antara pelarut etanol dengan ekstrak dilakukan dengan rotary evaporator suhu $70-80^{\circ} \mathrm{C}$ sehingga didapatkan ekstrak berupa padatan oily dari daun sirsak, ekstrak etanolik daun sirsak (EEDS). Selanjutnya dilakukan pengenceran menggunakan DMSO $<0,05 \% \mathrm{v} / \mathrm{v}$ untuk kepentingan studi farmakologis.

\section{Pengukuran Proliferasi Sel dengan MTT assay}

Sel dipanen, dihitung, diencerkan dengan media kultur lengkap sehingga jumlah sel yang ditransfer dalam 96- well plate adalah $5 \times 10^{3} \mathrm{sel} / \mathrm{sumuran}$. Selanjutnya ke dalam sumuran ditambahkan berbagai konsentrasi EEDS dan diinkubasi dalam inkubator $\mathrm{CO} 25 \% 37^{\circ} \mathrm{C}$ selama 24 dan 48 jam. Setelah inkubasi berakhir, medium dan EEDS dibuang, kemudian ditambahkan ke masing-masing sumuran $10 \mu \mathrm{l}$ reagen MTT (TACS MTT Cell Proliferation assay ${ }^{\circledR} 4890-25$ Cat-K) konsentrasi $0,5 \mathrm{mg} / \mathrm{ml}$ dalam keadaan gelap. 
Dilakukan inkubasi pada $37^{\circ} \mathrm{C} 4$ jam sampai terbentuk formazan. Pengamatan kondisi sel dilakukan dengan mikroskop inverted, kemudian formazan dielusikan dari sel dengan $150 \mu \mathrm{l}$ DMSO. Pembacaan hasil dilakukan dengan ELISA microplate reader pada absorbansi $550 \mathrm{~nm}$. Proliferasi sel HeLa dinyatakan dalam bentuk prosentase dengan perhitungan menggunakan rumus :

$$
\% \text { proliferasi sel HeLa }=\frac{\text { OD perlakuan }- \text { blank }}{\text { rerata OD blank }- \text { kontrol }} \times 100 \%
$$

Konsentrasi EEDS pada masing-masing kolom sumuran ditentukan rata-rata untuk mendapatkan nilai $\mathrm{IC}_{50}$ yaitu dosis yang menyebabkan penurunan absorbansi sebanyak $50 \%$.

\section{Pengukuran Jumlah Sel Apoptosis menggunakan Flowcytometry}

Dilakuan inkubasi 24 well-plate dengan masing-masing sumuran mengandung $1 \times 10^{5}$ sel pada inkubator $\mathrm{CO}_{2} 5 \%$ 37 으 Setelah sel dikeluarkan dari inkubator, medium dan EEDS diaspirasi, kemudian dalam tiap sumuran tambahkan D-PBS, EDTA, tripsin dilanjutkan dengan inkubasi selama 2 menit pada inkubator $\mathrm{CO}_{2}$, kemudian semua aspirat diletakkan pada eppendorf dan dilakukan sentrifugasi pada kecepatan 2500 rpm selama 5 menit. Sel pada masing-masing eppendorf dicuci dengan PBS dingin. Sentrifugasi sel pada kecepatan $1500 \mathrm{rpm}$ pada suhu $4^{\circ} \mathrm{C}$. Tambahkan Annexin V, streptavidin, PI (Annexin $\checkmark$ Biotin Apoptosis Detection Kit e-Biosience cat. no.BMS500BT/300) dan inkubasi 10 menit pada suhu $4^{\circ} \mathrm{C}$ dalam gelap. Langkah terakhir adalah penambahan staining buffer sebanyak $300 \mu \mathrm{l}$ pada tiap sumuran. Analisis menggunakan flowcytometri pada waktu kurang dari 1 jam.

\section{Pengukuran Ekspresi dan Jumlah Protein p53 dengan Imunositokimia}

Jumlah sel yang ditransfer dalam 24- well plate yang sebelumnya telah diisi dengan cover slip adalah $5 \times 10^{3}$ sel/sumuran, dilanjutkan dengan menginkubasi sel sampai konfluen. Setelah sel pulih kembali, medium lama dibuang dan ke dalam tiap sumuran ditambahkan secara bertahap serum-free, medium dan EEDS, kemudian diinkubasi selama 24 dan 48 jam. Pada akhir waktu inkubasi, sel dicuci PBS kemudian ditambahkan metanol dingin. Ke dalam masing-masing sumuran ditambahkan secara berurutan $\mathrm{H}_{2} \mathrm{O}_{2} 3 \%$ dalam PBS pH 7,4, blocking buffer dan inkubasi 1 jam. Pada tiap sumuran ditambahkan antibodi primer (human anti p53 Santa Cruz cat. no.\#D07) dengan pengenceran 1:100 dalam PBS dengan $1 \%$ FBS. Sel diinkubasi semalam pada 4 으. Ke dalam masing-masing sumuran kemudian ditambahkan antibodi sekunder terbiotinilasi (KPL Affinity Purified Biotin Antibody to mouse IgG cat.no.216-1806), Streptavidin-HRP (Dako cat. no.00,032,671), AEC (Aminoethil Carbazole), setelah itu dicuci menggunakan $\mathrm{dH} 2 \mathrm{O}$. Mayer HE diteteskan ke masing-masing sumuran sebagai counterstaining kemudian dicuci dengan $\mathrm{dH}_{2} \mathrm{O}$.Coverslip kemudian diangkat dan diletakkan pada deck glass yang sudah ditetesi gelatin $5 \%$. Preparat dibaca pada mikroskop Nikon E-100 pada pembesaran 400 kali dan difoto dengan coolpix E 4500.

\section{Metode Analisis Data}

Pembuktian hipotesis penelitian menggunakan uji komparasi One Way ANOVA dilanjutkan dengan uji Least Significant Difference (LSD) dan korelasi Pearson Product Moment. Derajat kepercayaan adalah $p<0,05$. Perhitungan analisis data dengan bantuan program piranti lunak SPSS 19.

HASIL

\section{Ekstrak etanolik daun sirsak pada proliferasi sel HeLa}

Data dari hasil penelitian dengan uji One Way ANOVA dan LSD menunjukkan perbedaan tidak signifikan proliferasi sel HeLa pada perlakuan ekstrak daun sirsak 24 jam (Gambar 1A). Perbedaan signifikan didapat setelah perlakuan 48 jam tampak pada Gambar B (ditunjukkan dengan notasi berbeda).
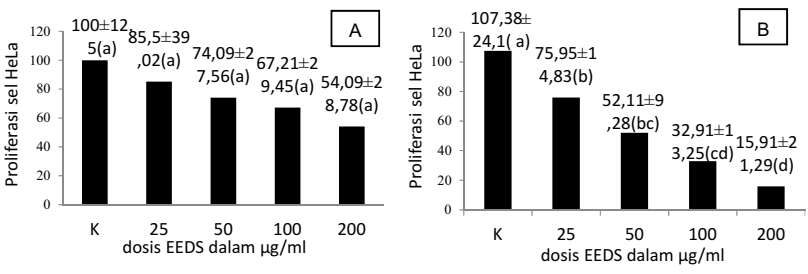

Gambar 1. Grafik nilai mean \pm standard deviasi proliferasi sel HeLa dengan perlakuan ekstrak etanolik daun sirsak 24 (A) dan 48 (B) jam

Nilai IC $\mathrm{C}_{50}$ pada penelitian ini adalah $111,75 \mu \mathrm{g} / \mathrm{ml}$ setelah paparan ekstrak etanolik daun sirsak selama 48 jam. Gambar 2 menggambarkan nilai absorbansi yang digunakan untuk menentukan nilai $\mathbf{~ c}_{50}$.

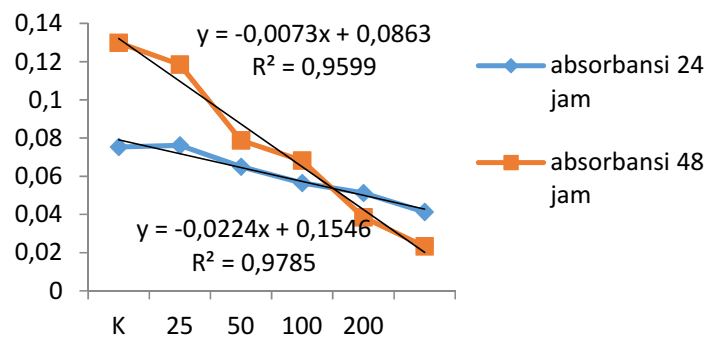

Gambar 2. Grafik nilai absorbansi sel HeLa 24 dan 48 jam

Efek Ekstrak Etanolik Daun Sirsak terhadap Apoptosis Sel HeLa

Berdasar uji komparasi didapatkan hasil adanya perbedaan yang signifikan indeks apoptosis sesudah pemberian ekstrak daun sirsak. Pemberian ekstrak etanolik daun sirsak selama 24 dan 48 jam pertama menyebabkan peningkatan apoptosis $(15,71+/-7,39)$ dibandingkan kontrol $(1,43+/-0,21)$ pada dosis $200 \mu \mathrm{g} / \mathrm{ml}$ dalam 24 jam pertama (Gambar 3A). Proses dilanjutkan dengan terjadinya apoptosis lanjut pada pemberian ekstrak etanolik daun sirsak selama 48 jam dosis $200 \mu \mathrm{g} / \mathrm{ml}$ (Gambar 3B). 

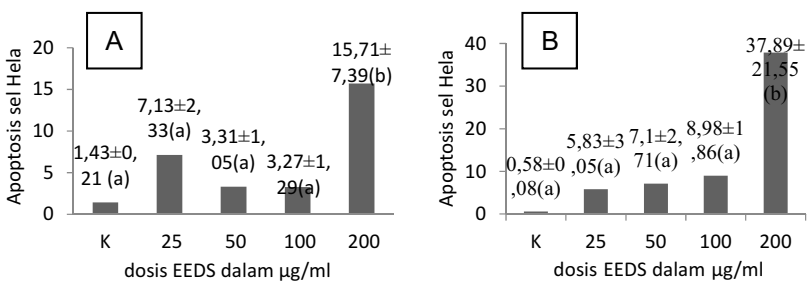

Gambar 3. Grafik nilai mean \pm standar deviasi sel HeLa dengan perlakuan EEDS yang mengalami apoptosis dini paparan 24 jam (A) dan apoptosis lanjut paparan 48 jam (B)

\section{Efek Ekstrak Daun Sirsak pada Aktivasi p53}

Ekstrak daun sirsak mampu meningkatkan ekspresi p53 pada sel HeLa baik selama paparan 24 maupun 48 jam pertama pada berbagai tingkatan dosis. Gambar 4 menunjukkan ekspresi p53 pada inti sel HeLa yang semakin nyata terlihat pada peningkatan pemberian dosis dan lama paparanran 48 jam (B).

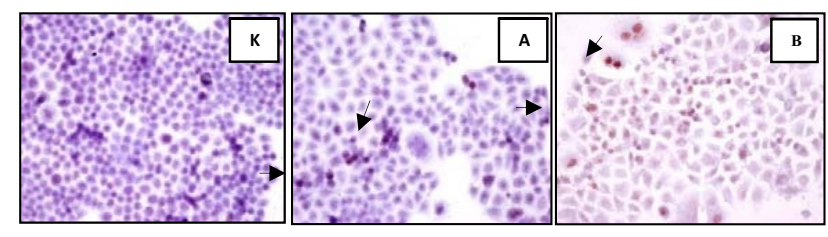

Gambar 4. Gambaran ekspresi p53 pada sel HeLa dengan perlakuan EEDS. Pada perbesaran 400x, sel HeLa dengan inti bewarna merah (panah hitam) adalah sel HeLa yang mengekspresikan p53.

\section{Keterangan}

(K) adalah sel HeLa tanpa perlakuan EEDS; (A) sel HeLa dengan perlakuan EEDS 24jam dan (B) sel HeLa dengan perlakuan EEDS 48 jam

Hasil uji perbandingan kelima rerata ekspresi p53 menunjukkan perbedaan bermakna. Hasil uji LSD menyimpulkan ada perbedaan signifikan antara mean jumlah P53 kelompok kontrol, dengan kelompok perlakuan pada semua dosis (tampak notasi huruf yang berbeda pada gambar 5A dan B).
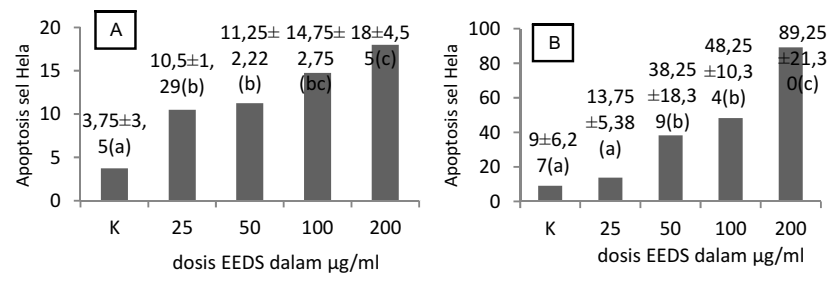

Gambar 5. Grafik nilai mean \pm standar deviasi jumlah ekspresi p53 sel HeLa dengan perlakuan EEDS 24 (A) dan 48 jam (B)

Uji korelasi menunjukkan hubungan negatif yang signifikan aktivasi p53 dengan proloferasi sel HeLa pada 24 dan 48 jam. Hasil penelitian juga menunjukkan korelasi positif antara p53 dengan apoptosis dini pada 24 jam dan apoptosis lanjut pada 48 jam.
Tabel 1. Korelasi jumlah ekspresi P53 dengan proliferasi dan apoptosis ( 24 dan 48 jam)

\begin{tabular}{lcccc}
\hline \multirow{2}{*}{ Parameter } & \multicolumn{2}{c}{ 24 jam } & \multicolumn{2}{c}{ 48 jam } \\
\cline { 2 - 5 } & $\mathbf{r}$ & $\mathbf{p}$ & $\mathbf{r}$ & $\mathbf{p}$ \\
\hline P53-Proliferasi (\%) - & 0,510 & $0,022-$ & 0,762 & 0,000 \\
P53-Apoptosis dini(\%) - & 0,590 & 0,006 & $-0,167$ & 0,482 \\
P53-Apoptosis lanjut(\%) - & 0,103 & 0,667 & 0,663 & 0,001 \\
\hline
\end{tabular}

\section{DISKUSI}

Proliferasi sel merupakan salah satu karakteristik yang dimiliki oleh setiap makhluk hidup untuk dapat tumbuh, berkembang dan mempertahankan kehidupannya. Proliferasi sel terjadi dalam rangkaian proses yang dikenal dengan nama siklus sel. Siklus sel dalam perjalanannya dikontrol secara ketat oleh dua mekanisme yaitu checkpoint siklus sel dan proses apoptosis. Adapun komponen-komponen yang bekerja dalam proses pengontrolan siklus sel tersebut adalah: (1) produk gen tumor supresor seperti CDK inhibitor, protein kinase cek poin, p53, p38, ATM, ATR, CHK 1 dan 2; (2) jalur ubikuitin proteasome (17).

Penelitian mengidentifikasi proliferasi sel HeLa terjadi sesudah 24 jam. Proliferasi merupakan contoh kejadian genomik. Kejadian genomik merupakan suatu proses kompleks dan terdiri dari beberapa tahapan dimana tiap tahapannya membutuhkan durasi waktu, seperti pada proses transkripsi, translasi, sampai dengan kerja serangkaian protein untuk menimbulkan efek metabolik yang dalam hal ini diwakili oleh proliferasi. Teori pendudukan reseptor yang dikemukakan oleh Meintein berisikan tiga konsep diantaranya adalah: (1) efek obat akan muncul karena adanya interaksi obat-reseptor dalam sel; (2) intensitas efek obat berbanding lurus dengan fraksi reseptor yang diikat; (3) fraksi reseptor tergantung beberapa hal diantaranya adalah dosis dan lama paparan. Semakin lama paparan dan semakin tinggi dosis, intensitas efek obat akan meningkat. Konsep ini mendukung temuan di penelitian ini yaitu penurunan proliferasi baru terjadi pada pemberian ekstrak dengan lama paparan 48 jam, dan meningkat sesuai penambahan dosis ekstrak etanolik daun sirsak.

Apoptosis diartikan sebagai kematian sel terprogram. Apoptosis merupakan salah satu fenomena kejadian yang memiliki peran penting dalam pengaturan aktivitas seluler pada organisme eukariotik. Karakteristik perubahan morfologi dari apoptosis adalah kondensasi kromatin dan sitoplasma, membran blebbing, fragmentasi DNA, pembentukan badan apoptosis dan pemaparan fosfatidilserin ke bagian luar membran sel. Agen-agen anti kanker menginduksi terjadinya apoptosis jalur intrinsic (18). Apoptosis dini dicirikan oleh sel yang sudah berkomitmen untuk mati dengan sederet perubahan morfologis yang telah disebutkan di atas dimana salah satu diantaranya adalah terpaparnya fosfatidilserin sebagai lapisan membran plasma terluar untuk pengenalan sel fagosit. Sel apoptosis dini jika tidak segera difagositosis dapat berkembang menjadi sel apoptosis lanjut atau disebut juga dengan sel nekrosis sekunder, dengan ciri terjadinya kebocoran membran plasma. Salah satu faktor utama yang menyebabkan perubahan status dari 
apoptosis dini ke apoptosis lanjut adalah kegagalan dari proses klirens atau pembuangan sel apoptosis (19). Perubahan status apoptosis dini ke apoptosis lanjut pada penelitian ini dapat dijelaskan dengan ketiadaan makrofag atau sel fagosit lain pada kultur sel HeLa. Sel HeLa yang mulai mengalami apoptosis dini pada perlakuan ekstrak etanolik daun sirsak 24 jam pertama mengalami serangkaian proses metabolisme akibat ketiadaan sel fagosit, sehingga membran plasmanya mengalami kebocoran.

Penelitian ini mengungkapkan kemungkinan penjelasan mekanisme ekstrak daun sirsak dalam menghambat pertumbuhan dan menginduksi kematian sel kanker serviks yang belum pernah dilakukan pada penelitianpenelitian terdahulu. Secara garis besar penurunan proliferasi dan induksi apoptosis sel HeLa disebabkan oleh dua mekanisme: (1) jalur tergantung p53; (2) jalur lain yang tidak tergantung p53. Banyak kemungkinan alternatif jalur stabilisasi dan aktivasi p53 oleh ekstrak daun sirsak, diantaranya adalah melalui (1) jalur langsung dan (2) tidak langsung. Menurut Sakaguchi (1999) penghilangan inhibisi pada domain C-terminal dari p53 akan secara langsung mengaktifkan p53 (20). Shaulsky (1996) menyatakan bahwa perubahan lokasi subseluler p53 dari sitoplasmik ke inti juga akan membuat p53 yang sebelumnya bersifat laten menjadi stabil dan aktif (21). Kemungkinan mekanisme langsung lainnya adalah melalui modifikasi kovalen dari p53. Tipe modifikasi kovalen yang bisa menstabilkan dan mengaktifkan p53 adalah penambahan gugus fosfat (fosforilasi), asetilasi, glikosilasi baik pada domain $\mathrm{N}$-terminal maupun $\mathrm{C}$ terminalnya. Mekanisme tidak langsung stabilisasi dan aktivasi p53 oleh ekstrak daun sirsak dapat dijelaskan sebagai berikut, yaitu (1) melalui induksi langsung kerusakan DNA dengan target pasangan basa, enzim timidilat sintase, toposimomerase, mikrotubulus pada proses mitosis; (2) modifikasi protein onkogenik virus HPV resiko tinggi E6; dan (3) bahan aktif daun sirsak berfungsi sebagai inhibitor proteasome.

Mekanisme yang tidak tergantung p53 bisa menjadi alternatif kemungkinan lain kerja ekstrak daun sirsak dalam menurunkan proliferasi, menginduksi apoptosis sel HeLa. Beberapa mekanisme tersebut diantaranya adalah: (1) sebagai inhibitor enzim telomerase; (2) modifikasi protein E7; (3) inhibitor ABC transporter seperti $p$ glikoprotein; (4) peningkatan ekspresi HSP9O yang berperan kemungkinan dalam proses pelipatan protein onkogenik sehingga didegradasi oleh proteasome.

Berdasar kajian-kajian teoritik diatas kemungkinan kuat salah satu mekanisme ekstrak daun sirsak dalam menyebabkan penurunan proliferasi dan induksi apoptosis pada sel HeLa adalah melalui stabilisasi dan aktivasi p53. Hal ini dibuktikan dengan peningkatan bermakna ekspresi p53, dan korelasi yang signifikan antara p53 dengan proliferasi dan apoptosis sel HeLa baik 24 maupun 48 jam. Ekspresi p53 yang dimulai lebih awal yakni pada 24 jam pertama dengan dosis terendah sementara proliferasi sel HeLa menurun mulai pemaparan 48 jam pertama dan apoptosis sel HeLa baru dimulai pada pemaparan ekstrak daun sirsak dengan dosis $200 \mu \mathrm{g} / \mathrm{ml}$ merupakan data pendukung peran kunci p53 dalam mengatur proliferasi dan apoptosis.

Sesuai dengan landasan teori terjadinya kanker serviks, bahwa p53 sel kanker serviks sebagian besar tidak mengalami mutasi. Protein p53 pada sel kanker serviks tidak stabil dan inaktif dikarenakan interaksi protein E6 HPV dengan p53. E6 membentuk kompleks dengan p53 dan menyebabkan degradasi dari p53 yang dimediasi oleh jalur ubikuitin-proteasome. Proses degradasi ini melibatkan protein seluler lain yaitu E6AP yang berperan sebagai ubikuitin ligase E3. Hasil ini didukung juga dengan teori maupun laporan-laporan sebelumnya bahwa peningkatan stabilisasi dan aktivasi p53 berperan sebagai pemain kunci baik pada proses proliferasi maupun apoptosis dengan cara berperan sebagai protein regulator transkripsional gen-gen yang terlibat di dalamnya. Keterlibatan p53 pada proses proliferasi adalah pada proses cell cycle arrest dan perbaikan kerusakan DNA. Gengen yang diaktifkan transkripsinya oleh p53 untuk menghambat proliferasi adalah WAFI/CIP1/p21, Gadd45, 14-3-3. WAFI/CIP1/p21 adalah gen yang menyandi protein CDK inhibitor yang jika terekspresi akan menyebabkan hipofosforilasi $\mathrm{Rb}$ sehingga E2F inaktif. Gadd45 yang menyandi protein Gadd45 berfungsi untuk memberhentikan siklus sel dengan cara meningkatkan kerja p21 sebagai inhibitor CDK. Protein p43 yang merupakan hasil transkripsi translasi 14-3-3 berperan sebagai regulator negatif kemajuan siklus sel pada fase G2/M (22,23). Protein Bax dan Bak merupakan protein proapoptosis yang transkripsinya diaktifkan oleh p53. Induksi ekspresi Bax dan Bak akan menyebabkan peningkatan permeabilitas mitokondria secara langsung. Puma dan Noxa adalah dua gen lain yang menyandi protein BH3 dan berperan juga pada jalur intrinsik apoptosis, dimana diaktifkan transkripsinya oleh p53 (24).

Protein p53 merupakan protein umur pendek, sehingga dikatakan juga protein ini tidak stabil. Ketidakstabilan protein ini semakin diperberat pada kasus kanker serviks karena protein onkogenik E6 bekerjasama dengan E6AP bekerja memediasi degradasi proteosomal p53. Karena p53 tidak stabil maka p53 secara otomatis tidak dapat menjadi aktif. Salah satu tanda p53 aktif adalah terjadinya akumulasi p53 di inti sel. Peningkatan jumlah ekspresi p53 hasil uji imunositokimia pada hasil penelitian ini secara tidak langsung menjadi bukti tambahan terjadinya stabilisasi dan aktivasi p53 setelah pemaparan dengan ekstrak daun sirsak pada sel HeLa. Data ini juga didukung oleh hasil penelitan Yuan SF (2003) bahwasanya annonacin menginduksi ekspresi p53, p21, Bax serta Bak. Dari faktafakta yang diperoleh disertai dengan kajian teoritik yang telah diuraikan diatas, maka hipotesis yang menyatakan bahwa ekstrak daun sirsak dapat menurunkan proliferasi, meningkatkan apoptosis melalui stabilisasi dan aktivasi p53 pada sel HeLa terbukti, khususnya pada perlakuan 48 jam.

Hasil penelitian menunjukkan inhibisi proliferasi sel HeLa baru terjadi pada 48 jam pertama paparan ekstrak etanolik daun sirsak, sementara induksi apoptosis sudah tampak pada 24 jam pertama. Hasil penelitian juga menunjukkan peningkatan aktivasi p53. Dalam literatur p53 dikatakan berperan dalam menginduksi terjadinya cell cycle arrest atau dan apoptosis (25). Induksi cell cycle arrest atau apoptosis atau kedua-duanya oleh p53 tergantung tipe sel dan tipe stress (25). Studi literatur belum ada yang menjelaskan apakah induksi cell cycle arrest mendahului apoptosis atau sebaliknya. Beberapa penelitian menyatakan bahwa jika kerusakan DNA yang terjadi sangat 
parah, dimana mekanisme perbaikan DNA tidak mampu mengatasi, maka sel lewat perantara p53 lebih lanjut akan menginduksi proses apoptosis $(22,26)$. Konsep ini sesuai dengan data penelitian, dimana prosentase apoptosis 48 jam lebih besar dua kali lipat $(37,89 \%)$ dibanding dengan 24 jam (15,71\%).

Penelitian ini membuktikan adanya penurunan proliferasi dan peningkatan apoptosis sel HeLa pada kanker dengan pemberian ekstrak daun sirsak dengan kemungkinan

\section{DAFTAR PUSTAKA}

1. Liao JB. Viruses and Human Cancer. Yale Journal of Biology and Medicine. 2006; 79: 115-122.

2. Chakrabarti $\mathrm{O}$ and Krishna S. Molecular Interaction of High Risk Human Papillomavirus E6 and E7 Oncoproteins: Implications for Tumor Progression. Journal of Biosciences. 2003; 28(3): 337-348.

3. Phelps WC, Yee CL, Munger K and Howley PM. The Human Papillomavirus Type 16 E7 Gene Encodes Transactivation and Transforming Functions Similar to Adenovirus E1A. Cell. 1988; 53(4): 539-547.

4. Scheffner $M$, Huibregtse JM, Vierstra R and Howley PM. The HPV-16 E6 and E6-AP Complex Functions as a Ubiquitin-protein Ligase in the Ubiquitination of $p 53$. Cell. 1993; 75: 495-505.

5. SchmittE, Paquet $\mathrm{C}$, Beauchemin $\mathrm{M}$, and Bertrand R. Review: DNA-damage Response Network at the Crossroads of Cell Cycle Checkpoints, Cellular Senescence and Apoptosis. Journal of Zhejiang University Science B. 2007; 8(6): 377-397.

6. Borges $\mathrm{HL}$, Chao $\mathrm{C}, \mathrm{Xu} \mathrm{Y}$, Linden $\mathrm{R}$ and Wang JYJ. Radiaton-Induced Apoptosis in Developing Mouse Retina Exhibits Dose Dependent Requirement for ATM Phosporylation of p53. Cell Death and Differentiation. 2004; 11(5): 494-502.

7. Kim MK, KimTJ, Sung C, Choi CH, Lee J, and Bae D. Clinical Significance of HIF-2 $\alpha$ Immunostaining Area in Radioresistant Cervical Cancer. Journal of Gynecologic Oncology. 2011; 22(1): 144-148.

8. Li K, Li Q, Han Z, Li J, Gao D, Liu Z and Zheng F. Alkaloid from Angelicae Dahuricae Inhibits Hela Cell Growth by Inducing Apoptosis and Increasing Caspase-3 Activity. LabMedicine. 2008; 39(9): 540-546.

9. Kim TJ, Lee J, Song SY, Choi J, Kim BG, Lee J and Bae DS. Increased Expression of Pakt is Associated with Radiation Resistance in Cervical Cancer. British Journal of Cancer. 2006; 94: 1678-1682.

10. Alali FQ, Liu XX, and McLaughlin JL. Annonaceous Acetogenins: Recent Progress. Journal of Natural Product. 1999; 62(3): 504-540.

11. Betancur-Galvis LA, Saez J, Granados H, Salazar A, and Ossa JE. Antitumor and Antiviral Activity of Colombian Medicinal Plant Extracts. Memórias do Instituto Oswaldo Cruz. 1999; 94(4): 531-535.

12. Yuan SF, Chang $\mathrm{H}$, Chen $\mathrm{H}$, et al. Annonacin, a Monotetrahydrofuran Acetogenin, Arrests Cancer Cells at the G1 Phase and Causes Cytotoxicity in a Bax-and mekanisme melalui stabilisasi dan aktivasi p53. Proliferasi sel dan penurunan apoptosis merupakan salah satu mekanisme yang terjadi selama fase promosi dan progresi kanker, karenanya hasil penelitian kali ini bisa dijadikan dasar teoritik bahwa ekstrak etanolik daun sirsak dapat dijadikan kandidat agen terapeutik kanker. Kajian lebih lanjut mengenai gen-gen yang terlibat dalam mekanisme kerja daun sirsak dalam fase promosi, progresi, invasif dan metastasis perlu dilakukan.

Caspase-3-related Pathway. Life Sciences. 2003; 72: 2853-2861.

13. Oberlies NH, Croy VL, Harrison ML, and McLaughin JR. The Annonaceous Acetogenin Bullatacin is Cytotoxic Against Multidrug Resistant Human Mammary Adenocarcinoma (MCF-7/Adr) Cells. Cancer Letters. 1997; 115: 73-79

14. Degli EM, Ghelli A, Ratta M, Cortes D, and Estornell E. Natural Substances (Acetogenins) from the Family Annonaceae are Powerful Inhibitors of Mitochondrial NADH Dehydrogenase (Complex I). Biochemical Journal. 1994; 301(1): 161-167.

15. Zafra-Polo MC, Gonzalez MC, Estornell E, Sahpaz S, and Cortes D. Acetogenins from Annonaceae, Inhibitors of Mitochondrial Complex I. Phytochemistry. 1996; 42(2): 253-271.

16. Trubus. Daun Sirsak versus Kemoterapi. Jakarta; PT. Trubus Swadaya; 2011; hal. 15.

17. Lodish H, Berk A, Zipursky SL, Matsudaira P, and Darnell Y. Molecular Cell Biology. 5th edition. New York: WH Freeman \& Company; 2003.

18. Elmore S. A Review of Programmed Cell Death. Toxicologic Pathology. 2007; 35(4): 495-516.

19. Poon IKH, Hulett MD and Parish CR. Molecular Mechanism of Late Apoptotic Cleareance. Cell Death and Differentiation. 2010; 17: 381-397.

20. Sakaguchi K, Herrera JE, Saito S, et al. DNA Damage Activates $p 53$ through a Phosphorylation-acetylation Cascade. Science. 1998; 281: 1677-1679

21. Shaulsky G, Ben-Zeev A, and Rotter V. Subcellular Distribution of the p53 Protein during the Cell Cycle of Balb/c 3T3 Cells. Oncogene. 1990; 5: 1707-1711.

22. Liebermann DA, Hoffman B, and Vesely D. p53 Induced Growth Arrest versus Apoptosis and its Modulation by Survival Cytokine. Cell Cycle. 2006; 2(2): 166-170.

23. Kastan MB, Zhan Q, El-Deiry WS, et al. A Mammalian Cell Cycle Checkpoint Pathway Utilizing p53 and GADD45 is Defective in Ataxia-telangiectasia. Cell. 1992; 71: 587-597.

24. Polyak K, Xia Y, and Zweier JL. A Model for p53-induced Apoptosis. Nature. 1997; 389: 300-305.

25. Bellamy COC. $p 53$ and Apoptosis. British Medical Bulletin. 1997; 53(3): 522-538.

26. Sionov RV and Haupt Y. The Cellular Response to p53: the Decision between Life and Death. Oncogene. 1999; 18: 6145-6157. 